\title{
PENINGKATAN HASIL BELAJAR TEMA SEHAT ITU PENTING MENGGUNAKAN MODEL PROBLEM SOLVING PADA SISWA KELAS 5 SDN NGENING 01, BATANGAN - PATI TAHUN 2014-2015
}

\author{
Hana Widyawati \\ Hanawidyawati.ukswpati@gmail.com \\ SDN Ngening 01 - Batangan, Kabupaten Pati
}

\begin{abstract}
ABSTRAK
Latar belakang masalah dalam penelitian ini adalah pendekatan saintifik sebagai proses kegiatan pembelajaran dari penerapan Kurikulum 2013 belum berfungsi dengan maksimal, sehingga menyebabkan rendahnya ketuntasan yang belum mencapai persentase minimal KKM yang ditentukan oleh sekolah. Dipilih model Problem Solving yang berpotensi untuk menerapkan pendekatan saintifik dalam meningkatkan kompetensi hasil belajar. Penelitian ini bertujuan untuk mengetahui apakah model Problem Solving melalui pendekatan saintifik dapat meningkatkan hasil belajar muatan IPA pada siswa kelas 5 SDN Ngening 01 Tahun Pelajaran 2014/1015. Penelitian ini terdiri dari 2 siklus, siklus I terdiri dari 3 kali pertemuan dan siklus II terdiri dari 3 kali petemuan. Subjek dalam penelitian ini adalah siswa kelas 5A SDN Ngening 01 yang berjumlah 20 siswa dengan karakteristik yang heterogen. Pembelajaran mengacu pada langkah-langkah model Problem Solving yang terdiri atas lima tahapan yaitu mengidentifikasi permasalahan, membatasi permasalahan, menyusun hipotesis, mengumpulkan data, dan menguji hipotesis dengan membuat simpulan. Hasil penelitian menunjukkan adanya peningkatan rata-rata hasil belajar muatan IPA. Pada kondisi awal nilai rata-rata siswa yaitu 62,40 dengan persentase ketuntasan $40 \%$. Pada pembelajaran Siklus I dengan menerapkan model Problem Solving, nilai rata-rata siswa meningkat menjadi 71,80 dengan persentase ketuntasan 50\%. Pada pembelajaran siklus II nilai rata-rata siswa 87,15 dengan persentase ketuntasan $100 \%$. Dengan demikian dapat disimpulkan bahwa model Problem Solving dapat meningkatkan hasil belajar muatan IPA siswa kelas 5A SDN Ngening 01.
\end{abstract}

Kata kunci: Problem Solving, pendekatan saintifik, hasil belajar IPA

\section{PENDAHULUAN}

Pendekatan saintifik sebagai proses kegiatan pembelajaran dari penerapan Kurikulum 2013 belum berfungsi dengan maksimal, sehingga menyebabkan rendahnya ketuntasan yang belum mencapai persentase minimal KKM yang ditentukan oleh sekolah. Diperlukan model pembelajaran yang berpotensi untuk menerapkan pendekatan saintifik dalam meningkatkan kompetensi hasil belajar. Model pembelajaran yang akan diterapkan dipilih model problem solving. Setelah 
tindakan pembelajaran dilakukan, diharapkan rata-rata tingkat keterampilan saintifik siswa pada kegiatan pembelajaran dapat mencapai kompetensi yang lebih baik, dengan jumlah siswa yang sudah mencapai ketuntasan belajar minimal meningkat.

Berdasarkan uraian tersebut maka identifikasi masalah dalam penelitian ini adalah guru masih menggunakan model ceramah yang kurang memberikan fasilitas kepada siswa untuk mengembangkan keterampilan saintifik dan meningkatkan hasil belajar. Guru lebih menekankan kepada penguasaan sejumlah fakta dan konsep saja, kurang memberikan fasilitas kepada siswa untuk mengembangkan kreatifitas, kurang menekankan pada penguasaan kemampuan dasar ilmiah atau keterampilan sain. Kurangnya motivasi belajar, rendahnya rasa ingin tahu, terbatasnya ruang ekspresi yang kreatif dan rasa takut untuk menyampaikan pendapat merupakan komponen dari aspek siswanya.

Pembatasan masalah penelitian ini adalah penerapan model Problem Solving melalui pendekatan saintifik untuk meningkatkan hasil belajar muatan IPA tema Sehat itu Penting pada siswa kelas 5 SDN Ngening 01 Kecamatan Batangan Kabupaten Pati Tahun Pelajaran 2014 / 2015.

Dengan demikian dapat dirumuskan permasalahan pada penelitian ini adalah bagaimana penerapan problem solving melalui pendekatan saintifik dalam meningkatkan hasil belajar muatan IPA Tema Sehat itu Penting pada siswa kelas 5 SDN Ngening 01 Kecamatan Batangan Kabupaten Pati Tahun Pelajaran 2014 / 2015? Dan apakah hasil belajar muatan IPA Tema Sehat itu Penting pada siswa kelas 5 SDN Ngening 01 Kecamatan Batangan Kabupaten Pati Tahun Pelajaran 2014 / 2015 dapat ditingkatkan dengan penerapan problem solving melalui pendekatan saintifik?

Tujuan penelitian ini adalah menerapkan problem solving melalui pendekatan saintifik dalam meningkatkan hasil belajar muatan IPA Tema Sehat itu Penting pada siswa kelas 5 SDN Ngening 01 Kecamatan Batangan Kabupaten Pati Tahun Pelajaran 2014 / 2015. Dan meningkatkan hasil belajar muatan IPA Tema Sehat itu Penting pada siswa kelas 5 SDN Ngening 01 Kecamatan Batangan Kabupaten Pati Tahun Pelajaran 2014/2015 dengan penerapan problem solving melalui pendekatan saintifik.

Secara teori manfaat penelitian ini adalah memberi keyakinan secara teoretis bahwa penelitian dapat menambah khasanah ilmu pengetahuan, khususnya dalam bidang pendidikan dengan meyakinkan secara teoretis bahwa model problem solving melalui pendekatan saintifik dapat meningkatkan hasil belajar muatan IPA Tema Sehat itu Penting. Sedangkan manfaat praktisnya ada untuk beberapa pihak, yaitu bagi siswa dapat meningkatkan hasil belajar muatan IPA Tema Sehat itu Penting. Bagi guru dapat meningkatkan keterampilan dalam melaksanakan 
pendekatan saintifik pada kegiatan pembelajaran, sedangkan bagi sekolah dapat menambah referensi penerapan model problem solving untuk guru yang lain.

\section{KAJIAN TEORI}

\section{Pembelajaran Tematik}

Pembelajaran tematik merupakan suatu pendekatan yang berorientasi pada praktik pembelajaran yang sesuai dengan kebutuhan perkembangan anak. Pembelajaran ini berangkat dari teori pembelajaran yang menolak proses latihan/ hafalan (drill) sebagai dasar pembentukan pengetahuan dan struktur intelektual anak. Teori belajar ini dimotori oleh para tokoh psikologi Gestalt, (termasuk teori Piaget) yang menekankan bahwa pembelajaran itu haruslah bermakna dan menekankan juga pentingnya program pembelajaran yang berorientasi pada kebutuhan perkembangan anak. Dampak dari penerapan pembelajaran tematik diketahui dengan melakukan evaluasi secara terpadu selama pembelajaran berlangsung. Tujuan evaluasi yang dilakukan untuk mengetahui perolehan hasil belajar siswa selama mengikuti kegiatan pembelajaran. Hasil belajar mengacu pada segala sesuatu yang menjadi milik siswa sebagai akibat dari kegiatan pembelajaran yang dilakukan (Hernawan, 2007: 10.20). Jenis-jenis hasil belajar menurut Bloom (dalam Hernawan, 2007: 10.29) antara lain:

1. Kognitif, yaitu hasil belajar yang berkenaan dengan pengembangan kemampuan otak dan penalaran siswa,

2. Afektif, yaitu hasil belajar mengacu pada sikap dan nilai yang diharapkan dikuasai siswa setelah mengikuti pembelajaran

3. Psikomotor, yaitu hasil belajar yang mengacu pada kemampuan bertindak.

\section{Pendekatan Saintifik}

Pendekatan yang digunakan dalam pembelajaran kurikulum 2013 adalah untuk penguatan sikap (tahu mengapa), keterampilan (tahu bagaimana), dan pengetahuan (tahu apa) yang terintegrasi, yaitu dengan pendekatan saintifik.

Pendekatan saintifik meliputi: mengamati, menanya, mencoba, mengolah, menyajikan, menyimpulkan, dan mencipta untuk semua mata pelajaran. Kurikulum 2013 menekankan penerapan pendekatan saintifik (meliputi: mengamati, menanya, mencoba, mengolah, menyajikan, menyimpulkan, dan mencipta untuk semua mata pelajaran) (Sudarwan, 2013). Komponen-komponen penting dalam mengajar menggunakan pendekatan saintifik (McCollum, 2009), yaitu:

1. Menyajikan pembelajaran yang dapat meningkatkan rasa keingintahuan (Foster a sense of wonder),

2. Meningkatkan keterampilan mengamati (Encourage observation), 
3. Melakukan analisis ( Push for analysis) dan

4. Berkomunikasi (Require communication) (Sudarwan, 2013).

\section{Model Problem Solving}

Dalam penelitian ini pembelajaran tematik dengan pendekatan saintifik menggunakan model Problem Solving. Model problem solving atau sering juga disebut dengan nama Model Pemecahan Masalah merupakan suatu cara mengajar yang merangsang seseorang untuk menganalisa dan melakukan sintesa dalam kesatuan struktur atau situasi di mana masalah itu berada, atas inisiatif sendiri. Dalam hal ini masalah didefinisikan sebagai suatu persoalan yang tidak rutin belum dikenal cara penyelesainnya. Justru problem solving adalah mencari atau menemukan cara penyelesaian (menemukan pola, aturan atau alogaritma).

Penyelesaian masalah menurut David Johnson dan Johnson dapat dilakukan melalui kelompok dengan prosedur penyelesaiannya dilakukan sebagai berikut (W.Gulo 2002: 117):

1. Mendifinisikan Masalah

2. Mendiagnosis Masalah

3. Merumuskan Alternatif Strategi

4. Menentukan dan Menerapkan Strategi

5. Mengevaluasi Keberhasilan Strategi

Berdasarkan pendapat para ahli, maka dapat disimpulkan langkah langkah yang harus diperhatikan oleh guru dalam memberikan pembelajaran problem solving sebagai berikut:

1. Merumuskan masalah

Dalam merumuskan masalah kemampuan yang diperlukan adalah kemampuan mengetahui dan merumuskan suatu masalah.

2. Menelaah masalah

Dalam menelaah masalah kemampuan yang diperlukan adalah menganalisis dan merinci masalah yang diteliti dari berbagai sudut.

3. Menghimpun dan mengelompokkan data sebagai bahan pembuktian hipotesis

Menghimpun dan mengelompokkan data adalah memperagakan data dalam bentuk bagan, gambar, dan lain-lain sebagai bahan pembuktian hipotesis.

4. Pembuktian hipotesis

Dalam pembuktian hipotesis kemampuan yang diperlukan adalah kecakapan menelaah dan membahas data yang telah terkumpul.

5. Menentukan pilihan pemecahan masalah dan keputusan 
Dalam menentukan pilihan pemecahan masalah dan keputusan kemampuan yang diperlukan adalah kecakapan membuat alternatif pemecahan, memilih alternatif pemecahan dan keterampilan mengambil keputusan.

Penerapan problem solving dengan kemampuan saintifik sesuai standar proses dapat mendorong kemampuan siswa untuk menghasilkan karya kontekstual baik individual maupun kelompok, karena pada kurikulum 2013 pada tataran proses pembelajaran memperkuat pendekatan ilmiah atau saintifik tematik terpadu dan tematik dalam suatu mapel akan mengupayakan agar guru mampu menerapkan pembelajaran berbasis penyingkapan atau penelitian yang dapat memecahkan sebuah permasalahan, sejak dari kegiatan perencanaan proses pembelajaran, pelaksanaan pembelajaran dan penilaian hasil pembelajaran, pengawasan proses pembelajaran untuk terlaksananya proses pembelajaran yang efektif dan efisien, sehingga siswa dapat dengan kompeten menerapkan pendekatan saintifik untuk menjawab persoalan dari materi pembelajaran.

\section{Kerangka Pikir}

Penelitian tindakan kelas dengan menerapkan model pembelajaran problem solving melalui pendekatan saintifik dalam pelaksanaan tindakan perbaikan pembelajaran sebagai upaya meningkatkan hasil belajar siswa kelas 5 SDN Ngening 01 Kecamatan Batangan Kabupaten Pati pada tema Sehat itu Penting.

\section{Hipotesis}

Rumusan hipotesis penelitian ini adalah penerapan problem solving melalui pendekatan saintifik untuk meningkatkan hasil belajar muatan IPA Tema Sehat itu Penting pada siswa kelas 5 SDN Ngening 01 Kecamatan Batangan Kabupaten Pati Tahun Pelajaran 2014 / 2015. Dilakukan dengan cara menyajikan persoalan sehingga siswa mampu mengidentifikasi masalah, memperjelas dan membatasi masalah, menyusun hipotesis, mengumpulkan data dan informasi, dan menguji hipotesis dan membuat simpulan dengan menggunakan pendekatan saintifik pada setiap kegiatan yang dilakukannya baik secara individu atau berkelompok dan selanjutnya mempersentasikan hasil belajarnya sesuai dengan materi muatan IPA Tema Sehat itu Penting.

\section{METODE PENELITIAN}

Jenis penelitian yang dipilih adalah Penelitian Tindakan Kelas (PTK). Menurut Kemmis dan Mc Taggart (dalam Pusparini, 2014: 50) penelitian tindakan dapat dipandang sebagai suatu siklus spiral dari penyusunan perencanaan, 
pelaksanaan tindakan, pengamatan (observasi), dan refleksi yang selanjutnya mungkin diikuti dengan siklus spiral berikutnya.

Penelitian Tindakan Kelas dilaksanakan pada semester I tahun pelajaran 2014/2015 pada tema Sehat itu Penting.Siklus I terdiri dari dua kali pertemuan yang dilaksanakan pada tanggal 4, 6 dan 8 November 2014. Siklus II juga terdiri dari dua kali pertemuan yang dilaksanakan pada tanggal 11, 13 dan 15 November 2014. Subjek penelitian adalah kelas 5 SDN Ngening 01 Kecamatan Batangan Kabupaten Pati. Kelas 5 SDN Ngening 01 merupakan kelas pararel yang terdiri dari dua kelas, yaitu kelas 5A dan kelas 5B. Penelitian Tindakan Kelas dilaksanakan pada siswa kelas 5A yang terdiri dari 10 siswa laki-laki dan 10 siswa perempuan.Siswa kelas 5A SDN Ngening 01 memiliki karakteristik daya serap dalam menerima materi ajar yang berbeda-beda. Ada siswa yang daya serapnya tinggi, ada yang sedang ada pula yang rendah. Oleh karena itu peneliti memilih kelas 5A sebagai subjek penelitian dengan penerapan model problem solving melalui pendekatan saintifik.

Variabel yang diteliti ada dua yaitu variabel bebas dan variabel terikat. Variabel bebas dalam penelitian ini adalah model Problem Solving, karena model Problem Solving melalui pendekatan saintifik mempengaruhi hasil belajar. Sedangkan variabel terikat dalam penelitian ini adalah hasil belajar muatan IPA pada tema Sehat itu Penting (Y). Hasil belajar dalam hal ini merupakan nilai pengetahuan yang diperoleh siswa pada akhir subtema sehingga akan diketahui tingkat keberhasilan siswa dalam proses pembelajaran.

Model problem solving merupakan penyajian materi pelajaran yang menghadapkan siswa pada persoalan yang harus dipecahkan atau diselesaikan untuk mencapai tujuan pembelajaran. Dalam pembelajaran ini siswa melakukan penyelidikan otentik melalui pendekatan saintifik untuk mencari penyelesaian terhadap masalah yang diberikan. Mereka menganalisis dan mengidentifikasikan masalah, mengembangkan hipotesis, mengumpulkan dan menganalisis informasi dan membuat kesimpulan. Berikut ini tahapan penelitian tindakan kelas dengan menerapkan model problem solving melalui pendekatan saintifik:

1. Rencana Tindakan Siklus I
a. Perencanaan
b. Pelaksanaan Tindakan Siklus I
c. Observasi
d. Refleksi

2. Rencana Tindakan Siklus II
a. Perencanaan
b. Pelaksanaan Tindakan Siklus II
c. Observasi
d. Refleksi 
Pengumpulkan data pada penelitian ini dengan menggunakan beberapa cara, yaitu melalui metode observasi, metode tes dan metode dokumentasi.

Metode observasi menggunakan lembar observasi aktivitas guru dan lembar observasi aktivitas siswa. Metode tes menggunakan tes tertulis berupa soal bentuk pilihan ganda berjumlah 20 soal. Metode dokumentasi berupa studi dokumentasi dilakukan terhadap buku siswa dan daftar nilai siswa kelas 5A SDN Ngening 01 dan foto selama penelitian.

Soal tes yang digunakan untuk evaluasi sudah diujikan terlebih dahulu dan divalidasi dengan menggunakan SPSS 18.0 for Windows. Sebuah instrumen dikatakan valid apabila mampu mengukur apa yang diinginkan. Hasil perhitungan validitas menggunakan SPSS 18.0 for Windows dari 20 item soal pretest siklus I di kelas 5B SDN Ngening 01 adalah valid semua karena memiliki koefisien cronbach's alpha if item deleted $<0,813$. Untuk menentukan tingkat reliabilitas instrumen mengunakan kriteria yang dikemukakan oleh George dan Mallery (2000) didasarkan pada nilai koefisien Alpha Cronbach $(\alpha)$.

Data hasil observasi aktivitas guru dan siswa dengan model problem solving melalui pendekatan saintifik dianalisis menggunakan teknik analisis deskriptif kualitatif. Sedangkan untuk data nilai hasil belajar muatan IPA dianalisis menggunakan teknik analisis deskriptif komparatif sehingga dapat dibandingkan nilai hasil belajar muatan IPA setelah tindakan siklus I dan siklus II.

Indikator keberhasilan adalah tanda atau ciri khusus yang menunjukan bahwa tujuan penelitian tercapai, terdiri dari indikator keberhasilan guru dan indikator keberhasilan siswa. Indikator keberhasilan guru antara lain guru bisa mengelola pembelajaran lebih menarik, menyenangkan dan bermakna dengan menerapkan model problem solving. Aktivitas pengelolaan pembelajaran dapat dikatakan berhasil jika terdapat peningkatan secara signifikan minimal $75 \%$ dari seluruh pembelajaran yang terlaksana. Serta guru dapat meningkatkan pemahaman dan keterampilan sain siswa melalui pendekatan saintifik dan mengalami ketuntasan belajar individual dengan nilai hasil belajar muatan IPA $\geq 70$ sesuai dengan KKM yang sudah ditentukan oleh sekolah. Indikator hasil dalam penelitian ini yaitu hasil belajar muatan IPA. Penerapan model problem solving melalui pendekatan saintifik dapat meningkatkan hasil belajar muatan IPA apabila siswa kelas 5A SDN Ngening 01 secara signifikan mengalami ketuntasan belajar individual dengan nilai hasil belajar muatan IPA $\geq 70$ dan mengalami ketuntasan belajar secara klasikal dengan nilai rata-rata hasil belajar IPA meningkat minimal 7 nilai dari KKM $\geq 70$ yang ditentukan oleh sekolah atau ketuntasan belajar secara klasikal sebesar $100 \%$ dari 20 siswa (kriteria sangat baik) dalam pembelajaran muatan IPA. 


\section{HASIL PENELITIAN DAN PEMBAHASAN}

Hasil belajar muatan IPA siswa kelas 5A mengalami peningkatan dari kondisi awal, dapat diketahui adanya peningkatan nilai rata-rata siswa yang pada kondisi awal 62,4 menjadi 71,8 pada siklus I. Hasil belajar muatan IPA siswa kelas 5A mengalami peningkatan dari hasil belajar pada siklus I, ditandai dengan meningkatnya perolehan nilai rata-rata siswa dari 71,8 pada siklus I menjadi 85,00 pada siklus II. Dapat dilihat pada gambar 1 di bawah ini:

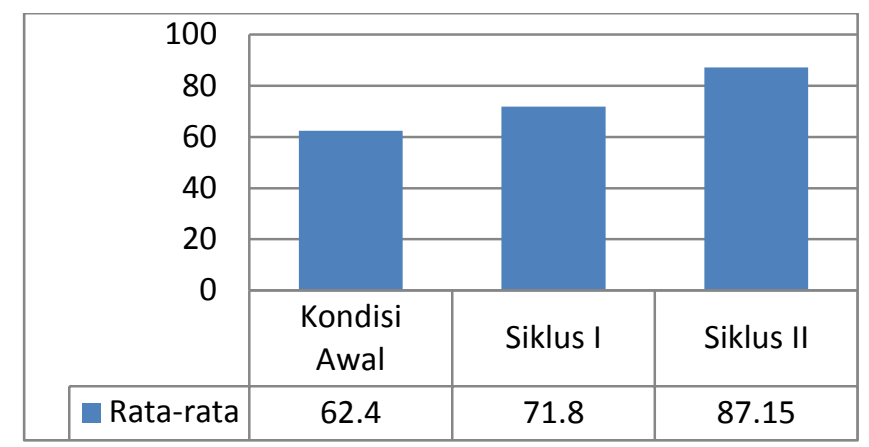

Gambar 1. Diagram Peningkatan Rata-rata Hasil Belajar IPA Kondisi Awal, Siklus I, dan Siklus II

Rata-rata skor observasi aktivitas guru dan siswa diketahui terjadi peningkatan aktivitas guru dan siswa dari siklus I dan siklus II dengan penerapan model problem solving melalui pendekatan saintifik. Setelah pelaksanaan tindakan siklus I rata-rata skor aktivitas guru mencapai 73 dengan persentase 91,25\%. Pada siklus II rata-rata skor aktivitas guru mengalami peningkatan menjadi 76,5 dengan persentase 95,63\%. Dengan adanya peningkatan aktivitas guru, rata-rata skor aktivitas siswa juga mengalami peningkatan. Pada siklus I rata-rata skor aktivitas siswa 71 dengan persentase $88,75 \%$, kemudian pada siklus II rata-rata skor meningkat menjadi 75 dengan persentase 93,75\%. Untuk menjelaskan perbandingan rata-rata hasil analisis skor observasi aktivitas guru dan siswa pada siklus I dan siklus II dapat diketahui pada gambar 2 sebagai berikut: 


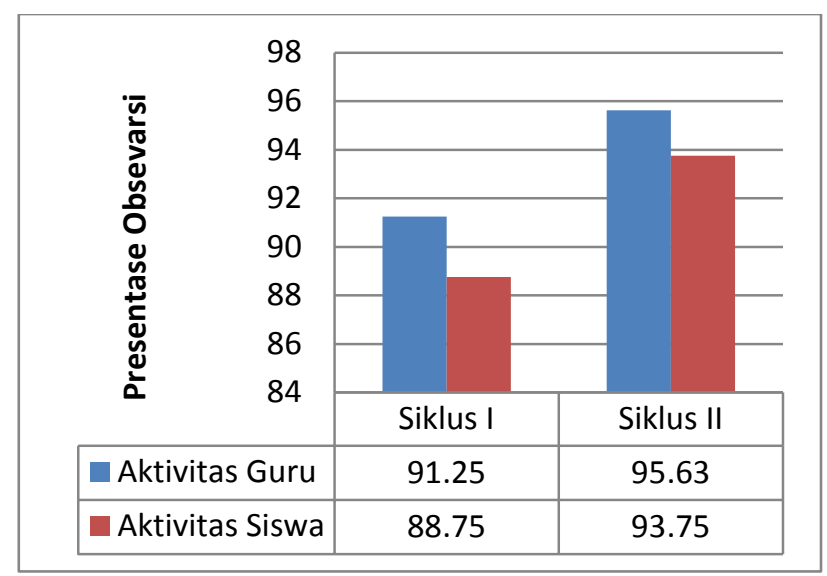

Gambar 2. Diagram Perbandingan Analisis Rata-rata Observasi Siklus I dan Siklus II

Penerapan model problem solving melalui pendekatan saintifik dalam pembelajaran tema Sehat itu Penting pada muatan IPA pada siswa kelas 5A Semester I SDN Ngening 01 Tahun Pelajaran 2014/2015 ini selaras dengan hasil penelitian yang telah dilakukan sebelumnya oleh Huda, dari penelitian tersebut diketahui rata-rata hasil belajar mata pelajaran IPA meningkat dari 78 pada siklus I menjadi92 pada siklus II setelah penerapan model problem solving, selanjutnya penelitian oleh Ibnu Purwanto juga menunjukkan hasil yang sama pada mata pelajaran Matematika bahwa dengan menerapkan model problem solving dapat meningkatkan hasil belajar dengan peningkatan nilai rata-rata siswa dari 60,33 menjadi 81,33. Selain itu penelitian yang dilakukan oleh Sri Lestari juga menunjukkan hasil yang sama pada mata pelajaran Matematika persentase nilai rata-rata kelas meningkat dari 72,5 menjadi 95,5. Dari hasil penelitian tersebut terbukti bahwa penerapan model problem solving dapat meningkatkan hasil belajar.

\section{SIMPULAN}

Penerapan problem solving dengan langkah-langkah mengidentifikasi masalah, memperjelas dan membatasi masalah, menyusun hipotesis, mengumpulkan data dan informasi, menguji hipotesis dan membuat simpulan dengan pendekatan saintifik, antusias siswa di dalam proses pembelajaran meningkat. Hal ini terbukti dengan adanya peningkatan aktivitas, baik aktivitas guru maupun aktivitas siswa dalam tiap siklusnya. Rata-rata hasil observasi aktivitas guru siklus I mencapai 91,25\%, pada siklus II rata-rata hasil observasi aktivitas guru 95,63\%. Rata-rata hasil observasi aktivitas siswa siklus I mencapai 88,75\%, untuk siklus II besarnya rata-rata hasil aktivitas siswa mencapai 93,75\%. 
Dengan meningkatnya hasil aktivitas guru dan aktivitas siswa maka berpengaruh terhadap hasil belajar muatan IPA. Hal ini dapat dibuktikan dari perolehan nilai siswa kondisi awal hingga pada pelaksanaan tiap siklusnya yang mengalami peningkatan secara signifikan. Pada kondisi awal mula-mula nilai ratarata hasil belajar muatan IPA siswa kelas 5A SDN Ngening 01 adalah 62,40 dengan persentase ketuntasan siswa sebesar $40 \%$. Kemudian setelah pelaksanaan tindakan siklus I dengan menerapkan model problem solving hasil belajar muatan IPA siswa kelas 5A mengalami peningkatan dari perolehan kondisi awal sebelumnya, nilai rata-rata yang diperoleh siswa setelah pelaksanaan tindakan siklus I menjadi 71,80 dengan besarnya persentase ketuntasan 50\%, kemudian setelah pelaksanaan tindakan pembelajaran pada siklus II nilai rata-rata hasil belajar muatan IPA meningkat menjadi 87,15 dengan persentase ketuntasan $100 \%$. Sehingga penerapan model problem solving terbukti dapat meningkatkan hasil belajar muatan IPA siswa kelas 5A SDN Ngening 01 Tahun Pelajaran 2014/1015.

\section{DAFTAR PUSTAKA}

George, D. \& Mallery, P. 2000. SPSS/PC + Step By Step, A Simple Guide and Reference. Belmont: Wadsworth Publishing Co.

Huda. 2012. Penerapan Model Problem Solving Untuk Meningkatkan Pembelajaran IPA di Kelas VI SDN Bangelan 04 Kecamatan Wonosari Kabupaten Malang. Skripsi Jurusan Kependidikan Sekolah Dasar \& Prasekolah - Fakultas Ilmu Pendidikan UM, 2012. http://karya-ilmiah.um.ac.id/index.php/KSDP/ article/view/19225

Kementrian Pendidikan dan Kebudayaan. 2013. Kurikulum 2013. Jakarta: Depdiknas.

Lestari Sri. 2013. Peningkatan Aktivitas Dan Hasil Belajar Membandingkan Bilangan 1 Sampai 500 Melalui Metode Problem Solving Pada Siswa Kelas II SD Negeri Karangmojo 03 Semester 1 Tahun Pelajaran 2012/2013. http://oramaido.blogspot.com/2013/09/ptk-sd-peningkatan-aktivitas-danhasil.html

McCollum, K. 2009. A Scientific Approach to Teaching. Tersedia di: http://kamccollum.wordpress.com/2009/08/01/a-scientific-approach-toteaching/ ( diakses tanggal tanggal 1 September 2014).

Purwanto, Ibnu. 2012. Peningkatan Hasil Belajar Matematika Melalui Model Pembelajaran Problem Solving Bagi Siswa Kelas V Semester I SDN Ronggo 01 Kecamatan Jaken Kabupaten Pati Tahun Pelajaran 2011/2012. Skripsi repository.library.uksw.edu.http://repository.library.uksw.edu/handle/123456 $789 / 653$

Pusparini Dwi Ratri. 2014. Upaya Peningkatan Hasil Belajar Mata Pelajaran IPA Melalui Model Pembelajaran Make A Match Berbantuan Media Gambar 
Scholaria, Vol. 5, No. 3, September 2015: 1 - 12

Pada Siswa Kelas 5 Semester II SDN Patemon 01 Tahun Pelajaran 2013/2014. Skripsi. Salatiga: S1 PGSD FKIP UKSW.

Slameto. 2011. Penelitian dan Inovasi Pendidikan. Widya Sari Press Salatiga.

Sudarwan. 2013. Pendekatan-pendekatan Ilmiah dalam Pembelajaran. Jakarta: Pusbangprodik

W. Gulo. 2012. Strategi Belajar Mengajar. Jakarta: Grasindo 